\title{
Interactive comment on "Past African dust inputs in Western Mediterranean area controlled by the complex interaction between ITCZ, NAO and TSI" by P. Sabatier et al.
}

\section{P. Sabatier et al.}

pierre.sabatier@univ-savoie.fr

Received and published: 27 November 2019

Dear Jean-Philippe Degai,

For ITCZ proxy we prefer use the Ti curve from Haug et al., (2001) because this one is more integrative than the one of Shanahan et al., (2009). ITCZ reconstitution from Cariaco basin (Haug et al., 2001) in related to Orinoco river input a âĂŐ880,000 km2 wide catchment, while the African monsoon reconstitution from Shanahan et al., (2009) was from a crater lake (Lake Bosumtwi). Thus, for this last reconstitution local effect could have a greater impact. Moreover, the reconstitution for Lake Bosumtwi cover just the last 2600 yrs while we present here a 3150 yrs archive of African dust record. 
However, this two ITCZ reconstitutions present many similarities in term of long and short term variations, even at decadal scale (Shanahan et al., 2009).

Haug, G. H., Hughen, K., Sigman, D. M., Peterson, L. C. and Röhl, U.: Southward Migration of the Intertropical Convergence Zone Through the Holocene, Science, 293(5533), 1304-1308, doi:10.1126/science.1059725, 2001.

Shanahan, T.M., Overpeck, J.T., Anchukaitis, K.J., Beck, J.W., Cole, J.E., Dettman,D.L., Peck, J.A., Scholz, C.A., King, J.W., 2009. Atlantic forcing of persistent drought inWest Africa. Science 324, 377-380.

Interactive comment on Clim. Past Discuss., https://doi.org/10.5194/cp-2019-111, 2019. 